\title{
An Exploratory Study of the Impact of the Summer English Teaching Service-learning Program in a Remote Area of Yunnan Province, China
}

\author{
Carol Hok Ka Ma ${ }^{1, *}$, and Fabia Shuk Ling Cheung ${ }^{2}$ \\ ${ }^{1}$ S R Nathan School of Human Development, Singapore Universit of Social Sciences, 461 Clementi \\ Road, Singapore 599491 \\ ${ }^{2}$ Project officer, Office of Service-Learning, Lingnan University, 8 Castle Peak Rd, Tuen Mun, \\ Hong Kong
}

\begin{abstract}
This exploratory study examines a three-year Summer English Teaching Service-Learning Program (SETSLP) in a high school in Yunnan, China. Students from Lingnan University acted as tutors to teach English to around 300 Chinese students of which 181 participants finished and returned the questionnaires over the three years of SETSLP through a Communicative Language Teaching (CLT) approach from 2009 to 2011. Results showed that CLT significantly (i) increased the students' selfperceived English abilities in the areas of listening $(t=2.62, p<.05$ in 2009; $\mathrm{t}=4.60, \mathrm{p}<.01$ in 2011), comprehension $(\mathrm{t}=2.33, \mathrm{p}<.05$ in $2009 ; \mathrm{t}$ $=5.16, \mathrm{p}<.01$ in 2010; $\mathrm{t}=7.11, \mathrm{p}<.01$ in 2011), and oral communication $(\mathrm{t}=2.22, \mathrm{p}<.05$ in $2009 ; \mathrm{t}=6.39, \mathrm{p}<.01$ in $2010 ; \mathrm{t}=7.85, \mathrm{p}<.01$ in 2011); (ii) increased the students' confidence in speaking English as most students throughout the three years chose oral ability as their greatest achievement in the program; and (iii) increased the students' interest and motivation in learning English. Students also revealed that SETSLP increased their interest in English and students were more motivated to learn English $($ Mean $=8.44, \mathrm{SD}=1.51)$. Besides, students mentioned that the tutors who participated in the service-learning program, played a crucial role to encourage and motivate them to learn English. This also teaches the students the importance of doing service-learning in their daily life.
\end{abstract}

Key words: Communicative language teaching (CLT), english teaching, impact, service-learning

\section{Introduction}

Service-Learning is a relatively new concept in China as this concept started in the United States in 1960 and then promoted to Asia in 2000. In 2006, the first regional conference on service-learning was held in Hong Kong and then there is a rapid development of service-

\footnotetext{
* Corresponding author: carolmahk@,suss.edu.sg
} 
learning in the region. More universities in Asia starts to adopt service-learning as a tool for teaching, for youth development, for national education and for character education.

Lingnan University has been using service-learning as a pedagogy in its education since 2006. Its longstanding motto is 'Education for Service' that emphasizes the importance of academic study and community service. Lingnan is the first University in Hong Kong set up the Office of Service-Learning (OSL) to encourage the interface between academic and community service. From 2006 to 2017, there were over 200 projects echoing the needs of the community. Service-learning becomes a powerful tool to realize the University motto and train the students to be more responsible and caring citizens.

The Summer English Teaching Service-Learning Program (SETSLP) was the first of this kind of program in China partnering with Deloitte China which is a commercial firm to sponsor and to do voluntary work for the SETSLP. The program was held at the Wu Ding No.1 Secondary School, which is located in a remote area of Yunnan Province. The SETSLP adopted the communicative language teaching (CLT) approach, which aims to develop students' communicative competence through interactive teaching methods, e.g. group discussion, opinion sharing, speaking training. Around 300 Senior Three students, who were preparing for the College Entrance Examination (CEE), also called Gaokao ${ }^{l}$, were taught by undergraduate students from Lingnan University, Hong Kong and Yunnan and the staff of Deloitte China. This article describes the experience of SETSLP and investigates whether it:

- Research Question 1(RQ1): increased the self-perceived English abilities in CEE of the students;

- Research Question 2 (RQ2): increased the students' confidence in speaking English; and

- Research Question 3 (RQ3): motivated the students to become more interested in English learning.

Questionnaires before and after SETSLP were collected to evaluate the learning outcomes of the students. Since China has one of the largest number of English learners in the world and English education in China is still in the developmental stage [1], this study can provide insights towards informal interactive English language teaching and learning in China, which is rarely addressed in the literature [2].

\subsection{English education in China}

English is the most widely learned and used foreign language in China, where around 300 million Chinese are learning English now. However, English teaching and learning is still in the developmental stage in China. In fact, English has been a compulsory subject for most Chinese high schools, colleges and universities for only around $30 \mathrm{yr}$ [1]. Since inception, English language education in Chinese high schools has employed a teachercentered, book-centered and grammar-centered approach, which emphasizes repetition and memorization. In the classroom, teachers spend most of their time and effort in "explaining text in detail, analysing grammar, paraphrasing sentences, asking detailed questions about the texts and making students practice patterns" [1]. The teachers act as knowledge transmitters and students as passive receivers. This top-down approach is being criticized for producing only test-takers, ignoring the importance of practical language skills, and preventing the students from developing a genuine interest in learning to speak English [1] . Because of these problems, the Ministry of Education designed and implemented the new English Curriculum Standards (ECS) for compulsory education in senior middle schools in

\footnotetext{
${ }^{1} \mathrm{CEE}$ or Gaokao is an important exam during secondary school to determinate whether you can study in tertiary education institutions in China.
} 
2001. ECS highlights the importance of activating students' interests in English learning, relating course content to students' real life, and students' active participation in the learning activities [1].

\subsection{English teaching through service-learning in China}

In view of the English education in China, there are various English teaching programs in China led by oversea Universities or Non-profit organizations (NPOs). Since 2006, Wayne State University has worked with Tsinghua University to offer summer service-learning English teaching program in rural China. Chinese students are paired with American volunteers to learn and practice English. Besides, Volunteer in Asia (VIA) is a long history NPO also offering service-learning opportunities for people to teach abroad, especially in Myanmar or China. Many of the above programs have not done any impacts study or even build in a proper survey. Thus, the SETSLP has its uniqueness. First, it was led by both University and a corporation. Second, it also built in a pre-post questionnaire to study the impacts of English teaching to the students (service target). In addition, all the participating tutors need to go through various training programs to understand the concept of servicelearning, village education system and English teaching preparation workshops. At last, this program has clear objectives to (i) increase students' self-perceived English abilities in CEE, (ii) increase students' confidence in speaking English and (iii) motivate students to become more interested in English learning.

\subsection{Communicative language teaching (CLT)}

To meet the learning goals of ECS, communicative language teaching (CLT) is believed to be a better choice than the teacher-centered, book-centered, and grammar-centered approach [3]. CLT is a language teaching method that aims to develop language users' communicative competence, meaning the ability to manipulate the language appropriately, fluently, and effectively [4]. CLT also emphasizes the establishment of interactive communicative activities in classrooms which are learner-centered with an emphasis on language use, fluency, authentic language and contexts, and negotiation of meaning, instead of practicing grammatical forms in isolation $[5,6]$.

However, there is a concern over whether the western-based CLT can be successfully applied or is even suitable for the Chinese cultural context (e.g. Hu [7]; Jarvis \& Atsilarat [8]), due to the examination-oriented education system of mainland China. Chinese teachers and students preferred grammar-based English learning because it can ensure a better score in the CEE, which puts most emphasis on grammar and vocabulary. Because of the concern with the CEE, students tend to learn English passively and engage in monotonous exercises without a real interest in the subject [4]. It has been found that more than $43 \%$ of students subjectively perceived their English proficiency level as poor and did not feel confident about learning English [9].

\subsection{The context of Yunnan}

Yunnan is a province of China located in the far southwest of the country. It spans approximately $394000 \mathrm{~km}^{2}$ (4.1\% of the total area of China) and has a population of 47 000000 [10]. Yunnan is a less developed area of China. In 2014, the annual GDP per capita in Yunnan was RMB 27 264, much lower than the average amount of RMB 46629 in China [11]. Unlike students in wealthier provinces whose parents can afford private tutors for English lessons at home, minority students in Yunnan and their parents can barely afford a trip to the county town and a nutritious meal [12]. Yunnan also has a higher 
illiteracy rate $(8.23 \%)$ than the national average $(4.92 \%)$ [11], meaning that more educational opportunities are needed in the area, as indicated by the lace of educational resources and well-qualified teachers in some remote cities and counties in Yunnan [13].

\subsection{SETSLP details and activities}

Taking past CEE examination papers and mock tests as references, three teams of tutors consisting of Hong Kong and Yunnan university students and staff of Deloitte China were given the freedom by the school principal to design the teaching content and activities for the Senior Three students at Wu Ding No. 1 Secondary School. The teaching curriculum consisted of three parts: English lessons (EL), English corner (EC) and mass activities (MA). As shown in Table 1, EL focused more on examination skills and strategies for preparing the written part of the CEE, while EC emphasized oral communication by using games and conversations. MA provided information about different study subjects at universities, scholarship opportunities, and actual study experiences in universities. The curriculum was adjusted every year based on the past year(s) experience.

Table 1. Summary of SETSLP Activities from 2009 to 2011.

\begin{tabular}{|c|c|c|c|}
\hline $\begin{array}{l}\text { SETSLP } \\
\text { Activities }\end{array}$ & English Lesson (EL) & English Corner (EC) & Mass Activities (MA) \\
\hline $\begin{array}{l}\text { Date and } \\
\text { Time }\end{array}$ & $\begin{array}{l}5: 00 \mathrm{pm} \text { to } 6: 00 \mathrm{pm} \\
\text { weekdays }\end{array}$ & $\begin{array}{l}12: 30 \mathrm{pm} \text { to } 1: 15 \mathrm{pm} \\
\text { weekdays }\end{array}$ & $\begin{array}{l}\text { Saturdays and/or } \\
\text { Sundays }\end{array}$ \\
\hline Duration & $1 \mathrm{~h}$ & $45 \mathrm{~min}$ & $1-3 \mathrm{~h}$ \\
\hline $\begin{array}{l}\text { Tutor- } \\
\text { student } \\
\text { Ratio }\end{array}$ & $\begin{array}{l}\text { About 1:40 (2009) } \\
\text { About 1:8 }(2010,2011)\end{array}$ & $\begin{array}{l}\text { About 1:8 }(2009,2010 \text {, } \\
\text { 2011) }\end{array}$ & $\begin{array}{l}\text { From } 1: 100 \text { to } 1: 800 \\
(2009) \\
\text { About } 1: 50(2010,2011)\end{array}$ \\
\hline $\begin{array}{l}\text { Classroom } \\
\text { Setting }\end{array}$ & $\begin{array}{l}\text { Sitting in rows }(2009) \\
\text { Sitting in groups }(2010 \text {, } \\
2011)\end{array}$ & $\begin{array}{l}\text { Sitting in groups (2009, } \\
2010,2011)\end{array}$ & $\begin{array}{l}\text { Sitting in rows (in big } \\
\text { halls) }(2009,2010,2011)\end{array}$ \\
\hline Syllabus & $\begin{array}{l}\text { The CEE syllabus: } \\
\text { Listening }(2009,2011) \\
\text { Cloze text }(2009,2010, \\
2011) \\
\text { Multiple-choice cloze } \\
\text { (2009, 2010, 2011) } \\
\text { Reading comprehension } \\
\text { (2009, 2010, 2011) } \\
\text { Fault correction (2009, } \\
\text { 2010, 2011) } \\
\text { Guided writing (2009, } \\
\text { 2010, 2011) } \\
\text { Phonetics (2010) }\end{array}$ & $\begin{array}{l}\text { Passage reading (2009, } \\
2010,2011) \\
\text { Conversation }(2009, \\
2010,2011) \\
\text { Mini speech }(2009, \\
2010,2011) \\
\text { Discussion and/or debate } \\
(2009,2010,2011) \\
\text { Phonetics }(2010)\end{array}$ & $\begin{array}{l}\text { One-minute theatre cum } \\
\text { movie sharing }(2009) \\
\text { University information } \\
\text { session }(2009,2010 \text {, } \\
2011) \\
\text { Life sharing session } \\
(2009,2010,2011)\end{array}$ \\
\hline
\end{tabular}

Continue on next page 
Table 1. Summary of SETSLP Activities from 2009 to 2011 (Continued).

\begin{tabular}{|c|c|c|c|}
\hline $\begin{array}{l}\text { SETSLP } \\
\text { Activities }\end{array}$ & English Lesson (EL) & English Corner (EC) & Mass Activities (MA) \\
\hline \multirow[t]{8}{*}{ Format } & \multirow{3}{*}{$\begin{array}{l}\text { Lectures on exam skills } \\
\text { and strategies }(2009 \text {, } \\
2010,2011)\end{array}$} & Greetings $(2009,2010$, & \multirow{5}{*}{$\begin{array}{l}\text { Movie shows (2009) } \\
\text { Performance by students } \\
\text { (2009) } \\
\text { Sharing talk by tutors } \\
(2009,2010,2011)\end{array}$} \\
\hline & & 2011) & \\
\hline & & Ice-breaking games & \\
\hline & \multirow{2}{*}{$\begin{array}{l}\text { In-class exercises and/or } \\
\text { mock exams }(2009, \\
2010,2011)\end{array}$} & $(2009,2010)$ & \\
\hline & & $\begin{array}{l}\text { One-minute dialogue } \\
(2009)\end{array}$ & \\
\hline & $\begin{array}{l}\text { Explanation of answers } \\
\text { and/or demonstration of } \\
\text { good or bad samples } \\
(2009,2010,2011)\end{array}$ & $\begin{array}{l}\text { English fun day (2010, } \\
\text { 2011) }\end{array}$ & \\
\hline & $\begin{array}{l}\text { Discussions among } \\
\text { students }(2009,2010 \text {, } \\
2011)\end{array}$ & & \\
\hline & $\begin{array}{l}\text { Question and answer } \\
\text { sessions }(2009,2010 \text {, } \\
2011)\end{array}$ & & \\
\hline
\end{tabular}

\section{Methodology}

\subsection{General}

This study adopted a quantitative method and used SPSS to analyze the data. Two sets of questionnaires, including pre and post questionnaires were collected. At the start of SETSLP, students were asked to fill in a pre-SETSLP questionnaire consisting of 45 items. The questionnaire had two parts. Part A asked the students to rate their English proficiency and their expected performance in seven (or eight) question types tested in the CEE. A 10point Likert-scale was used, ranging from "strongly disagree" (1) to "strongly agree" (10). Part B asked the students to write down their expectations and reasons for joining the program.

At the end of SETSLP, students had to fill in another questionnaire consisting of three parts. Part A covered the same items as Part A of the pre-SETSLP questionnaire to allow comparison on students' English proficiency and confidence in CEE performance before and after joining the SETSLP. Part B of the post-SETSLP questionnaire had 10-point Likert-scale questions (34 items in 2009; 28 items in 2010; 31 items in 2011), measuring other learning activities in SETSLP, such as EC and MA. Part B questions were adjusted slightly due to the changes of program content every year. In Part C, students were asked to answer three open-ended questions, including their biggest achievement after SETSLP, feedback to/for the tutors, as well as their other opinions about the program.

\subsection{Basic profiles}

From 2009 to 2011, around 300 students had the opportunity to join the program. They mostly came from the nearby villages and were from the lower class. Students were chosen based on four criteria:

i) they would be Senior Three students after the summer vocation;

ii) they were interested in English; 
iii) they scored highly in their English exams; and

iv) they were recommended by their English teachers.

A portion of the questionnaires was missing due to difficulties in practical administration, such as limited time for questionnaire collection during classes and no return of questionnaires by some students. At the end, 181 participants finished and returned the questionnaires over the three years of SETSLP (Table 2).

Table 2. Number and Percentage of Student Participants.

\begin{tabular}{cccc}
\hline \multirow{2}{*}{ Gender } & $\mathbf{2 0 0 9}$ & $\mathbf{2 0 1 0}$ & $\mathbf{2 0 1 1}$ \\
\cline { 2 - 4 } & Number (\%) & Number (\%) & Number (\%) \\
\hline Male & $11(28.2)$ & $22(46.8)$ & $27(28.4)$ \\
\hline Female & $28(71.8)$ & $25(53.2)$ & $68(71.6)$ \\
\hline Total & $39(100)$ & $47(100)$ & $95(100)$ \\
\hline
\end{tabular}

\section{Results}

\subsection{Self-perceived English abilities}

RQ1 asked whether SETSLP increased the students' self-perceived English abilities in CEE. Table 3 shows that for three consecutive years, students reported higher selfperceived abilities in the following skills:

(i) listening $(\mathrm{t}=2.62, \mathrm{p}<.05$ in $2009 ; \mathrm{t}=4.60, \mathrm{p}<.01$ in 2011),

(ii) comprehension $(\mathrm{t}=2.33, \mathrm{p}<.05$ in 2009 ; $\mathrm{t}=5.16, \mathrm{p}<.01$ in $2010 ; \mathrm{t}=7.11, \mathrm{p}<.01$ in 2011), and

(iii) oral communication $(\mathrm{t}=2.22, \mathrm{p}<.05$ in 2009 ; $\mathrm{t}=6.39, \mathrm{p}<.01$ in $2010 ; \mathrm{t}=7.85, \mathrm{p}<$ .01 in 2011).

In 2010, the listening section was replaced by the phonetics section and the improvement was also perceived as significant $(\mathrm{t}=4.65, \mathrm{p}<.01)$. Moreover, the improvement increased every year and reached the highest in all measured items in the third year.

Table 3. Students' performance in the past CEE tests.

\begin{tabular}{|c|c|c|c|}
\hline \multirow{2}{*}{ CEE Sections } & \multicolumn{3}{|c|}{ 2009 (n= 39) } \\
\cline { 2 - 4 } & Mean 1 (SD) & Mean 2 (SD) & t value \\
\hline Listening & $4.99(1.65)$ & $5.58(1.43)$ & $-2.62^{*}$ \\
\hline Multiple-Choice Cloze & $5.46(1.58)$ & $5.89(1.31)$ & -1.85 \\
\hline Cloze Text & $5.46(1.72)$ & $5.70(1.49)$ & -1.00 \\
\hline Comprehension & $5.15(1.56)$ & $5.70(1.28)$ & $-2.33^{*}$ \\
\hline Fault Correction & $5.78(1.67)$ & $5.86(1.31)$ & -0.35 \\
\hline Guided Writing & $5.58(1.40)$ & $5.82(1.32)$ & -1.09 \\
\hline
\end{tabular}

Continue on next page 
Table 3. Students' performance in the past CEE tests (Continued).

\begin{tabular}{|c|c|c|c|}
\hline \multirow{2}{*}{ CEE Sections } & \multicolumn{3}{|c|}{$2009(n=39)$} \\
\hline & Mean 1 (SD) & Mean $2(\mathrm{SD})$ & $\mathrm{t}$ value \\
\hline Oral & $4.22(1.62)$ & $4.83(1.54)$ & $-2.22 *$ \\
\hline \multirow[t]{2}{*}{ Phonetics } & --- & --- & --- \\
\hline & \multicolumn{3}{|c|}{$2010(n=47)$} \\
\hline Listening & --- & --- & --- \\
\hline Multiple-Choice Cloze & $5.22(1.57)$ & $6.64(1.49)$ & $-4.68 * *$ \\
\hline Cloze Text & $4.99(1.35)$ & $5.99(1.40)$ & $-3.61 * *$ \\
\hline Comprehension & $4.80(1.49)$ & $6.50(1.59)$ & $-5.16^{* *}$ \\
\hline Fault Correction & $4.32(1.46)$ & $5.96(1.95)$ & $-4.55 * *$ \\
\hline Guided Writing & $5.50(1.10)$ & $6.46(1.30)$ & $-3.72 * *$ \\
\hline Oral & $3.46(1.56)$ & $5.96(1.71)$ & $-6.39 * *$ \\
\hline \multirow[t]{2}{*}{ Phonetics } & $3.94(1.60)$ & $5.60(1.83)$ & $-4.65 * *$ \\
\hline & \multicolumn{3}{|c|}{$2011(\mathrm{n}=95)$} \\
\hline Listening & $5.78(1.75)$ & $6.43(1.64)$ & $-4.60 * *$ \\
\hline Multiple-Choice Cloze & $5.79(1.80)$ & $6.41(1.56)$ & $-4.36^{* *}$ \\
\hline Cloze Text & $5.44(1.94)$ & $6.25(1.80)$ & $-5.14 * *$ \\
\hline Comprehension & $5.39(1.82)$ & $6.46(1.67)$ & $-7.11 * *$ \\
\hline Fault Correction & $4.98(1.98)$ & $6.01(1.83)$ & $-6.64 * *$ \\
\hline Guided Writing & $5.63(1.62)$ & $6.38(1.53)$ & $-5.54 * *$ \\
\hline Oral & $4.61(1.82)$ & $5.89(1.59)$ & $-7.85 * *$ \\
\hline Phonetics & --- & --- & --- \\
\hline
\end{tabular}

\subsection{Confidence in speaking English}

RQ 2 asked whether SETSLP increased the students' confidence in speaking English. Figure 1 shows that over the three years, most students ( $24 \%$ to $37 \%$ ) chose oral ability as their greatest achievement in the program. From the post-SETSLP questionnaire conducted in 2011, students also strongly agreed that they "became more confident in speaking through everyday reading/daily speech session" (Item 22, Mean $=8.14, \mathrm{SD}=1.76$ ) and they were "more confident in speaking English than before" (Item 42, Mean $=8.53, \mathrm{SD}=$ 1.48). Students also expressed strong agreement with the statements of "I am more active in speaking English than before" (Item 41, Mean $=8.46, \mathrm{SD}=1.54$ ). These findings reflected that SETSLP increased the students' perceived oral skills and their confidence in speaking English. 

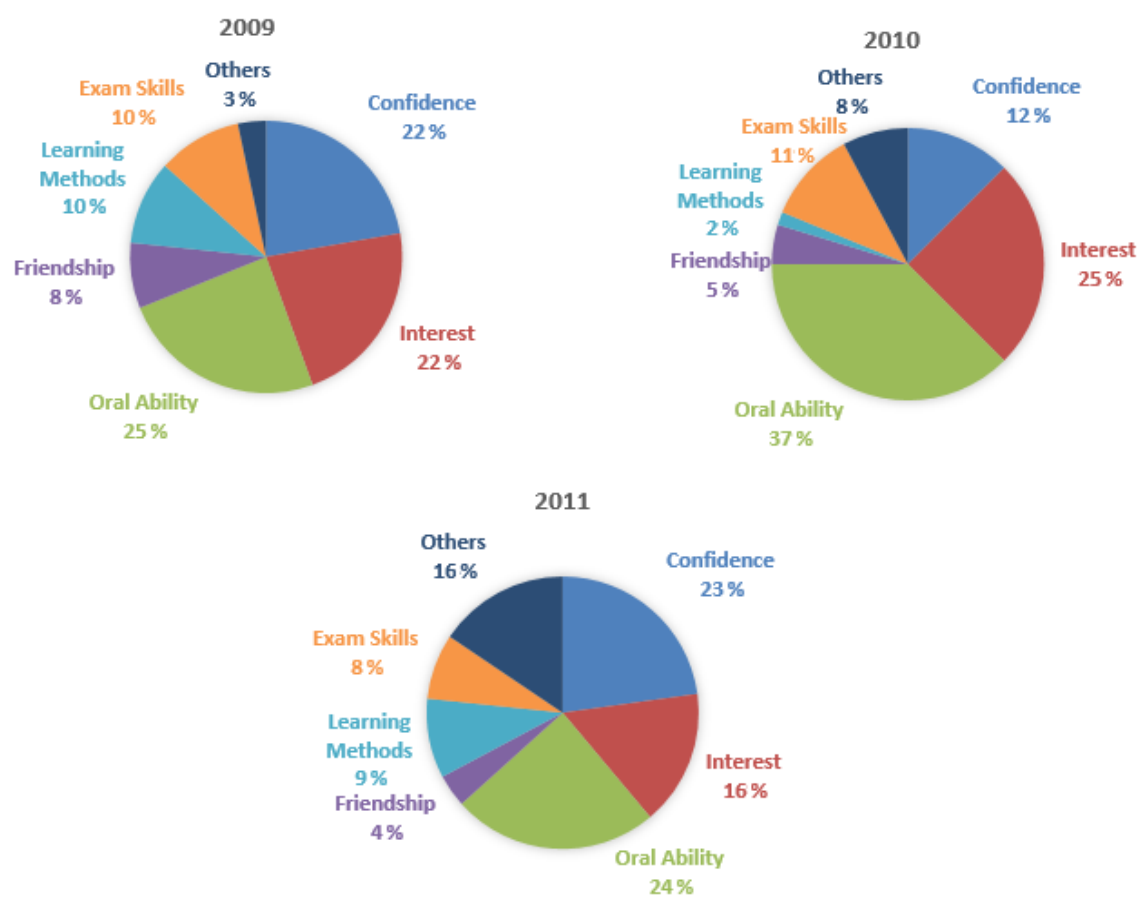

Fig. 1. Students' Biggest Achievement in SETSLP in 2009, 2010 and 2011.

\subsection{Interest and motivation in English learning}

RQ 3 asked whether SETSLP increased the students' interest and motivation in learning English. As shown in Figure 1, in 2009 and 2010, about a quarter of students $(22 \%$ to $25 \%)$ revealed that SETSLP increased their interest in English. From the post-SETSLP questionnaire conducted in 2011, students also gave a high score to the question of "I am more proactive in learning English than before" (Item 14, Mean = 8.44, SD = 1.51), meaning they were more motivated to learn English.

\section{Discussion and recommendations}

The results showed that the students' self-perceived English abilities in terms of speaking, listening and comprehension had significantly improved after SETSLP. They had also become more active and confident in speaking English. These results could be explained by the reason that CLT is more effective than the formal grammar-translation teaching methods in creating a more relaxed English learning environment, because it emphasizes interactive teaching activities and student-oriented teaching methods. In SETSLP, students had many opportunities to practice English speaking and listening through interactive and interesting activities like role-playing, either in class or in lecture theatre hall. Tutors would also invite students who had demonstrated their speech talents to make a short speech in front of the class. The results reflect that CLT can be successfully applied in the Chinese cultural context with diversified communicative activities, which significantly improved students' confidence in speaking English and interest in learning English. These positive findings show the Chinese students can actively participate in the lessons and gain 
more opportunities to speak English through CLT, which is learner-centered, and they accepted this approach to learn English in the classrooms. According to Xu and Guo (2017) [14], CLT is a very student-centered teaching method. It not only echoes to students' learning needs, styles and goals, but also allows teachers to design a series of communicative activities. These all can motivate students to learn and speak more during the class.

The tutors' continuous encouragement was a key factor in increasing the students' interest in learning English which lots of motivational strategy literatures also mentioned the importance of enhancing students' motivation and learning in their classrooms $[15,16]$. In CLT, teacher is viewed as the facilitator that encourages students' participation in the activities and communication in English [17]. Using SETSLP as an example, tutors would ease the students' fear of speaking English by emphasizing that it was entirely acceptable to make mistakes because practice led to improvement. Giving verbal encouragement and gift incentives (e.g. stationaries, reward stickers), were found to be effective in motivating the students to answer questions and speak English. Tutors wrote down encouraging words and gave reward stickers to motivate students to write in English. Detailed and immediate guidance from the tutors was found to be important for practicing the examination skills of students. For instance, normally, in order to practice English listening skills, the Chinese students listen to an audio broadcasting in the school at night and do the corresponding exercises on their own nearly every day. In this situation many students only judge the answers by one or two words that reach their ears without fully understanding whole conversation context. In SETSLP, however, when teaching the listening section of the CEE, the tutors would not only ask the students to pay attention to the audio content, but also ask them to find clues from the questions. These examples indicate that the role of tutors were still important in CLT although the tutors did not fully dominate the teaching process. Tutors' role was likely to become knowledge-guide, giving appropriate assistances to guide the students, instead of being the knowledge-transmitters. Thus, tutors themselves have generally enhanced their communication skills, social competence, research skills, organizational skills, problem solving skills and subject-related knowledge (English as a subject) and of course, their civic orientation. Though tutors are not our research targets, their impacts on participating in SETSLP has written in another report.

The class size was found to be highly related to the students' learning outcome. In 2009, the tutor-student ratio in the English lessons (EL) was 1:40. In 2010 and 2011, it changed to 1:8 with the financial support from Deloitte China. After this change, students' selfperceived English abilities had significantly increased (Table 3). Smaller classes not only allow teachers to have more interaction with the students, but also create a better learning environment [18]. It is shown that the range of class size may affect students' learning performance in CLT that students have better learning performance in the smaller class.

An interactive English environment can motivate students to learn English and make them stay confident about speaking English. While it is understandable that CLT may not be accepted by many high schools in China due to the time constraint of preparing for the CEE, it can be used in junior forms, when students have relatively less stress from exams. Also, teachers should encourage and praise the students in order to motivate them to learn English. This study gives an insight into how SETSLP affected the Senior Three Chinese students' English learning and what factors can motivate their interest in learning English through CLT. In order to implement a more effective CLT in contemporary China, further study on CLT is suggested to use experimental research to explore the differences of learning outcomes between traditional English language education in China and CLT and further examine how western-based CLT integrates into Chinese culture context.

At last, the results of how students learnt through this summer English teaching servicelearning model also proved that it is worth to continue training more university students to 
become tutors in the rural area of China. This is the first of this kind of program working with a corporation in China. With local government and corporation's support, the University should consider to encourage more students to do service-learning in China.

\section{Conclusion}

This study explores how the SETSLP that had been lasted for three years impacted students' English learning. The SETSLP is one of the unique service-learning programs that having university students and corporate volunteers as tutors to teach local students. The program was especially designed for the Senior Three Chinese students and aimed at providing students with the necessary examination skills to tackle the English examination as well as increasing their confidence in using English through CLT approach. The informal summer English program was different from traditional schooling due to its adoption of interactive and student-oriented teaching approach. By using CLT approach, students felt that their English abilities had increased, especially in the areas of oral communication, listening and comprehension. In addition, since students could practice spoken English in an enjoyable, relaxed and encouraging setting, they were more confident to use and speak English after the program. They also became more interested in learning English. Smaller class size may increase the effectiveness of interactive teaching methods, allowing more teaching activities in class. Generally, the students were satisfied with the format and content of the activities. They appreciated the classroom design, teaching methods and the tutors' advice in particular. Due to the pressure and the examination format of CEE, this paper suggests that teachers should start employing CLT as early as in the junior high schools because junior students do not face as much exam pressure as those in the higher grades.

\section{References}

1. X.T. Cheng. The "english curriculum standards" in China: rationales and issues. In: English language education across Greater China. A. Feng (Eds). Bristol, UK; Tonawanda, NY: Multilingual Matters (2011). p. 133-150. https://books.google.co.id/books/about/English_Language_Education_Across_Greate.ht ml?id=qlZQWWIPGssC\&redir esc $=\mathrm{y}$

2. M.J. Wighting, D.L. Nisbet, E.R. Tindall. Asia EFL. J, 7, 4:85-108 (2005). http://asianefl-journal.com/pta feb 06 mw.pdf

3. A. Karakaş. Journal of Second and Multiple Language Acquisition (JSMLA), 1, 1:1-20 (2013). http://jsmula.science-res.com/archives full issu/Vol $\% 201 \% 20$ issue $\% 201 \% 20$ full.pdf

4. S.M. Essossomo. Journal of Education and Practice, 4, 17 (2013). http://citeseerx.ist.psu.edu/viewdoc/download?doi $=10.1 .1 .888 .5928 \& \mathrm{rep}=\mathrm{rep} 1 \&$ type $=\mathrm{p}$ $\underline{\mathrm{df}}$

5. M. Holst.. 小樽㓏科大学人文研究, 123:191-230 (2012). https://barrel.repo.nii.ac.jp/?action=pages_view_main\&active_action=repository view main item detail\&item id=576\&item no $=1$ \&page $\mathrm{id}=13$ \&block $\mathrm{id}=135$

6. K.M. Ngoc, N. Iwashita. University of Sydney Papers in Tesol, 7:25-49 (2012). https://pdfs.semanticscholar.org/c545/b5aabbe098d1d96577beac0403fd75cb17c4.pdf

7. G. Hu, ELT. Journal, 59, 1:65-68 (2005). https://academic.oup.com/eltj/articleabstract $/ 59 / 1 / 65 / 429818$ ? redirectedFrom $=$ fulltext

8. H. Jarvis, S. Atsilarat. Asian EFL Journal, 6 ,4 (2004).

http://www.asian-efl-journal.com/Dec_04_HJ\&SA.pdf 
9. H. Zuo (1995). Analysis of the experimental College Entrance English Examination in the People's Republic of China. In: Theses and Dissertation for 1995, South Atlantic Review, 61, 4:165-190. J.R. Kelly (Eds). United States: Georgetown University (1996). https://www.jstor.org/stable/3201192?seq=1\#page scan tab contents

10. National Bureau of Statistics of China. China statistical yearbook 2014 [Online] from http://www.stats.gov.cn/tjsj/ndsj/2014/indexch.htm (2014). [Accessed on 22 November 2015]. [In Mandarin language]

11. National Bureau of Statistics of China. China statistical yearbook 2015 [Online] from http://www.stats.gov.cn/tjsj/ndsj/2015/indexch.htm (2015). [Accessed on 22 November 2015]. [In Mandarin language]

12. D.R. Blachford, M. Jones (2011). Trilingual education policy ideals and realities for the Naxi in rural Yunnan. In: English language education across Greater China. A. Feng (Eds). Bristol, UK; Tonawanda, NY: Multilingual Matters (2011). pp. 228-259. https://books.google.co.id/books/about/English_Language_Education_Across_Greate.ht ml?id=qlZQWW1PGssC\&redir_esc=y

13. A. Feng. English teaching and learning in ethnic minority regions in China: challenges and opportunities. In: Perspectives on teaching and learning english literacy in China, J. Ruan, C. Leung (Eds). Netherlands: Springer Netherlands (2012). pp. 129-143. https://link.springer.com/book/10.1007/978-94-007-4994-8

14. L. Xu, H.A. Guo. English Campus, 20:141 (2017). http://www.cqvip.com/read/read.aspx?id=7000265402

15. H. Cheng, Z. Dörnyei (2007). Innovation in Language. Learning and Teaching, 1, 1:153-174 (2007). http://dx.doi.org/10.2167/illt048.0

16. L. Wang, J. Vibulphol. OJED, 10, 1:429-443 (2015). https://tci-thaijo.org/index.php/OJED/article/download/40511/33431

17. D. Learsen-Freeman, M. Anderson. Techniques \& principles in language teaching. 3rd ed. New York: Oxford University Press (2011). pp. 159-176. https://elt.oup.com/teachers/tplt/?cc=id\&selLanguage $=\mathrm{id}$

18. L.B. Koenig, M. Gray, S. Lewis, S. Martin. International Journal of Humanities and Social Science, 5, 1:20-29 (2015)

http://www.ijhssnet.com/journals/Vol_5_No_1_January_2015/2.pdf 